\title{
Challenges Facing Trainees in Practical Skills Acquisition: The Case of Some TVET Colleges of Oromia Regional State, Ethiopia
}

\author{
Aman Gemechu Geda \\ Researcher at Defence University, Major General Mulugeta Buli Poly Technic College
}

\begin{abstract}
The major purpose of this study was to investigate challenges facing trainees in practical skill Acquisition in Some TVET Colleges of Oromia regional state. To attain this objectives, 180 (81 male, 42 female trainees) and 41 male and 6 female trainers, totally (180) respondents were selected using simple random sampling from five Colleges of Oromia regional state. Moreover, 5 Deans, 5 training process owners and 10 head departments of each sample colleges were purposely selected and included in the interview. The central question is What are the major challenges facing trainees in practical skill Acquisition in same TVET Colleges of Oromia regional state? To this end, Self report questionnaire and structural interview are the main tools for this research. The collected questionnaire is analyzed mainly by employing qualitative and quantitative approach. Simple percentage, mean and standard deviation are the main methods of data analysis. The analysis of data revealed that the major challenges facing trainees in practical skills Acquisition are shortage of training materials, incompatibility of training material with occupational standards, less attention given by the college to industrial attachments and the gap of trainers in applying the existing materials at practical training session. Likewise, there are trainers, who were carelessness in demonstrating their professional knowledge during practical skill training. The preparation of TTLM is different from college to college. Based on the findings, recommendations were made for concerned body to complement the colleges effort in the provision of basic training tools with given special packages and the colleges advised of effective industrial attachment schemes that will enable trainees to identify and gain practical knowledge required for the workplace through hands-on experience in local industries. Furthermore, central preparation of TTLM is recommended for the uniform provision training throughout the country. More importantly, for the quality betterment of practical skill training, concerned authority are advice to adopt project based training instead of competency based training which is currently in practice.
\end{abstract}

Keywords: Challenges, Assessment, occupational standards, trainees, trainers, center of competency, project based training, competency based training.

DOI: $10.7176 / \mathrm{JEP} / 12-4-02$

Publication date: February $28^{\text {th }} 2021$

\subsection{Back ground of the study}

Studies indicated that as the world come out from the current economic recession, the ability of a country to amplify the skills of its labor force is a significant concern to business and government. The need to increase employment opportunities and to enhance the workforce's social mobility through improved employability is particularly pressing in the countries of Africa and the governments of Africa are renewing efforts in promoting technical and vocational education and training (TVET) with the belief that skill formation enhances productivity and sustainability competitiveness in the global economy (Bhuwanee (2006). Moreover, one of the most important features of TVET, as recognized by African governments, is its orientation towards the world of work with the curriculum emphasizing the acquisition of employable skills African Union (2007). The report also stressed the current vision of African countries in developing a new policy to revitalize TVET in Africa. The expectation is that TVET will endorse skills acquisition through competency and project-based training. If this vision should materialize, it will require proficiency testing for employment in order to promote sustainable livelihoods and responsible citizenship.

There are a variety of challenges facing the effectiveness of the TVET sector that are widely accepted. Some of the key challenges include profession challenges, the disparity between possessed skills and market needs, prevalent concern about poor quality training and training environments, and negative community attitudes and perceptions towards vocational education and training Okebukola (2012), he further, stated that the challenges of TVET are abundant, which embrace inadequate human and material resources in terms of quality and quantity; in adequacy of funding of TVET, lack of in infrastructural facilities; poor quality preparation of training module by TVET trainers/ instructor ; and social associates. Similar studies conducted by Odu (2011) stated that, some of the challenges of Human Capital Development include insufficient funding; poor workshop preparation as per the current TVET system; and inadequate instructional materials. likewise, Okebukola (2012), reported that trainers inadequacies; funding inadequacies; disgusting insufficiency in facilities; harsh and un favorable training-room; unhealthy classroom; shortage of equipment; and social vices were among the challenges facing trainees during the requisite skills achievement. 
Many TVET graduates remain unemployed even in those occupational fields that show a high demand for skilled manpower. Thus, substantial resource wastages occurred as a result of underutilization of equipment in public TVET institutions (MoE2008) more importantly, under-funding is a structural problem in the TVET sector, particularly in the public system. Costs of TVET will remain high, if it is to be provided as centre based training, which is still the predominant mode of TVET delivery in Ethiopia. As with most other countries, public TVET programmes in Ethiopia are usually more expensive than general education, requiring lower than average teacher/student ratio and substantial capital and recurrent expenses incurred through practical training. As a consequence of budgetary constraints, most urban public TVET programmes are under-funded while rural public TVET programmes suffered from poor facilities and shortages of training materials (MoE2008)

\section{2 statements of the problem}

Technical and vocational educational training (TVET) of Ethiopia is to provide trainees with technical skills applicable in real word of work. The plan of Ethiopian government is to accelerate sustainable development to end poverty in order to achieve the development targets and TVET will need to provide "relevant demand driven training that responds to the need of economy and social sector for employment MoE (2008). According to Labour market analysis, establishment surveys, qualitative feedback from stakeholders and specific studies of cross-sect bodies: the influence of globalization, changing technology and new management practices is a result of a training system that long emphasized theoretical knowledge that is not aligned with modern technology obligations, disregarding the importance of practical skills and appreciation of the world of work(MoE2008).Moreover, related studies carried out by UNESCO (2011) in Ethiopia TVET Colleges revealed that both formal and non-formal TVET lacked an effective linkage between training and the real world of work. The study further noted that, because of its lack of logical mode, practical skills training do not produce the requisite skills for the job market. Additionally, the trainees also lacked training experience, initiative and motivation to discharge their duties effectively.

In his graduation speech to the Northern Virginia Community College in 2011), the Former President of the United States, Barack Obama stated, "If we could match up schools and businesses we could create pipelines right from the classroom to the office or the factory floor. This would help workers find better jobs, and it would help companies find the highly educated and highly trained people that they need in order to prosper and to remain competitive (Obama, 2011)." In other hand under-funding is a structural problem in the TVET sector particularly in the public system (MoE2008). Costs of TVET will remain high, if it is to be provided as centre based training, which is still the predominant mode of TVET delivery in Ethiopia. With respect to some TVET Colleges of Oromia regional states, there is no study conducted previously in the area, this study is tried to explore challenges facing trainees in practical skills acquisition in Some TVET colleges of Oromia regional state. To this end the following research question were raised.

\subsection{Research Questions}

1. What are the major challenges facing the trainees in practical skill Acquistion of Some TVET Colleges of Oromia regional State?

2. To what extent does the trainers' qualifications and quality of training affect the training of Practical skills?

3. What nature of connection has been there between the TVET Colleges of Oromia regional state and Industries

4. Is the training received by trainees of SomeTVET Colleges of Oromia Regional State is relevant to the world of work?

5. Do the practicum programs enhance to achieve the objectives stated in its competency outline?

\subsection{Objectives of the study \\ 1.4 1.General Objective}

The major objectives of this study are to discover challenges facing trainees in practical skill acquisition of some TVET Colleges of the Oromia Regional State.

\subsubsection{Specific Objective}

Specifically this study is intended to:

1. Identify the Major challenges facing trainees of Some TVET Colleges of Oromia Regional state.

2. Explore the extent of the trainers'/ instructors, qualifications and quality of training affects the training of practical skills

3. Explore the nature of connection between some TVET Colleges of Oromia Regional state and Industries

4. Examine if the training offered to trainees of some TVET Colleges of Oromia Regional State Colleges is relevant to the real world of work?

5. Discover the extents to which the practicum programs help in achieving the objectives stated in its 
competency outline.

\subsubsection{Significance of the Study}

The results of this study will give insight on the challenges facing trainees in practical skill acquisition. Moreover, Colleges Leaders, Trainees, Trainers/ Instructors of sample area colleges can be benefiting from the result of this study. Furthermore, the result of this study may also help to strengthen the connection between the colleges and Stakeholders as a foundation for the experience sharing with the remaining colleges found in Oromia regional state. In other hand, the result of this study will give information to the Wereda TVET coordination Office and Oromia TVET Commissions and to other concerned officials to take necessary measures. This study is expected to have academic and certain social contribution. More importantly this study can be a stepping stone for similar study.

\subsection{Review of Related Literature}

\subsection{Theoretical concepts}

Practical training is the focal point of all world country attention for its influence on the development of skills, and behaviors of trainees, where as a number of studies demonstrated its main role in bridging the gap between theory and practice that provides a framework for the Acquisition and development of trainees instructive and personal competencies (Smith and levari, 2005: 291). Practicum is still a subject of in conflict among scholars and educators and it occupies a large room in educational literature (schults, 2005), due to problems and challenges and barriers facing trainees, during practical skills achievement (Hamaidi, Al-shara, Abu Awwad, 2014). According to The National Board for Technical Education (NBTE, 2011), reported that the challenges of TVET sector include; low societal credit, which translate to low enrolment rate due to negative perception of the people to TVET and insufficient skilled workforce, out of date training facility, inadequate funding, unfortunate staffing, poor linkages with industry and general discrepancy in quality. In addition, evaluation in all sectors of education tends to be by conservative examinations, which generally does not factor in practical techniques in the industry. Miller (1985) Miller feels that successful vocational education requires the combining of two elements: Practice and thinking about the practice; and doing and thinking about the doing.

\subsection{Empirical evidence}

\subsubsection{Trainees competency based assessments for practical Skill Acquisitions}

Studies shows that successful "grasping up" countries, and particularly Hong Kong (China), Ireland, the Republic of Korea and Singapore, adopt a sectoral approach to identify skills and training needs for development(Shanahan and Hand, 2008). Competency-based training had its roots in early TVET, which originated in "early behaviorist models for career training have evolved over the decades to encompass college's curriculum that emphasize demonstrable workforce relevant outcomes or the application of acquired knowledge" (Ford, 2014). Competency-based education is focused on what the trainees knows and can perform. In addition, competency-based training does "not assume that successful completion of training module the results in the acquisition of training outcomes; rather, they confirm trainees training through individual assessment" (KleinCollins, 2014). As Klein-Collins confirmed that, competency-based training is a reply to identify for training, including higher technical college, to account for its planned outcomes both in the areas of productivity and effectiveness. At the college level, a competency-based approach has been adopted in the Bologna process, which involves 47 European countries adhering to the European Qualification Framework, and which seeks to standardize the offering of degrees by the countries involved by specifying the required programme content and learning outcomes (Benelux Bologna Secretariat 2009; Bünning \& Shilela, 2006).

\subsubsection{Limitations of Technical, Vocational and Education Training (TVET) Program}

(Rao1996) argues that the poor quality of training may be attributed to problems which include: lack of receptiveness of the curriculum to the changing labor market, decline in training standards, lack of maintenance facilities and equipment, lack of research and development. According to Atchoarena and Esquieu, (2002), public TVET institutions continued to attract a great deal of criticism. First, they were unable to train skilled work force to meet the requirements of enterprises and were unaware of the need for ongoing training. Second, they were extremely costly. In many countries, including Ethiopia, the public TVET institutions have not been able to adapt to the new structure of the labor market and the new skill requirements of companies in both the formal and informal sectors. It is important that the training provided in the TVET program facilitates the needs of the college environment and place the student at the center. The inclusions of practicum are a necessary step to provide in-service trainers and trainees with the experiences that should make the transition of the industry more practical. The addition of this aspect into the program of study provided relevance through practical experiences within the college and other training provision environments (Saaideh and Bin Tareef, 2011). The lack of understanding proved the need to discover the effectiveness of the program at this institution.

\subsubsection{Training Materials Utilization in TVET College}

Different studies show that as training particularly the TVET program to function as a total alteration of the 
trainees, Nwosu (2012) supporters changes for excellence training. This implies accessibility of instructional materials and improving classroom/virtual training facilities by adopting quality in order and communication resources which has offered unlimited access to knowledge and information on skill acquisition. Interactive communication tools in TVET colleges interactive are useful for the transformation of trainees and all people involved in the training and training process (Ibe-Bassey, 2011). They are critical tools that can be used in preparing and educating students with the required skills.

\subsubsection{TVET - Industry partnership}

According to UNESCO (2003) TVET is considered as an important element in human resource improvement with the general objective of preparing students with adequate knowledge and skills for life and the labor market. To achieve these intended objectives TVET contributors should establish effective corporations with stakeholders, in designing and structuring training system found in the labor market. Besides, TVET providers should develop institutional mechanism that will ensure the establishment of an excellence of instruction and the development of employment-linked competencies amongst graduates. On top of this, ILO (2001) states that vocational training has a direct impact on the productivity of an enterprise. Therefore, vocational training cannot be designed without taking into account the real needs of the real world of work

\subsubsection{Conceptual Framework}

Based on the research questions, literature's and presumed relationship between practice and challenges facing trainees in practical skills acquisition the conceptual framework underlines independent and dependent variables as indicated below

Independent variables

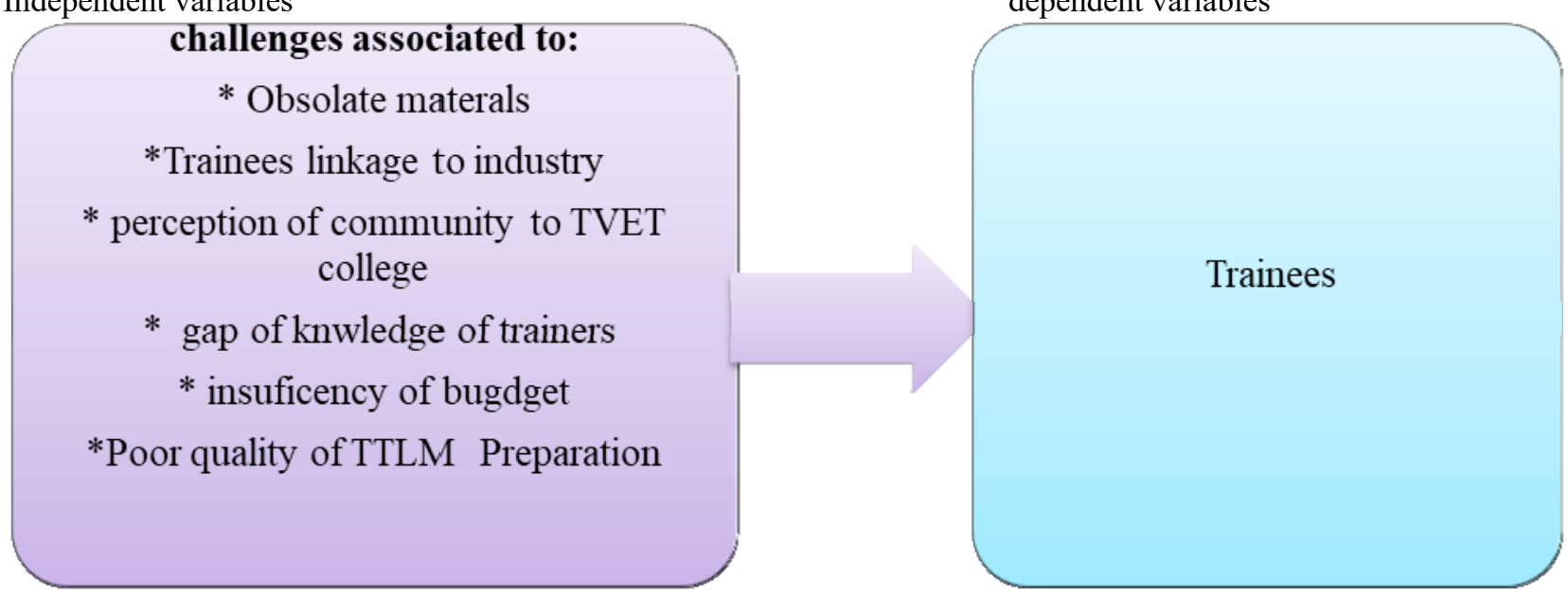

Fig 2.1 Conceptual Framework

Source: researchers own construction (2020)

\section{RESEARCH DESIGN AND PROCEDURE}

\subsection{Research Design associated}

The Researcher employed a survey research design i.e descriptive research, specifically mixed approach in carrying out the investigation. Through descriptive research survey design, the researcher were examined 5 Oromia TVET Colleges to conduct research on the challenges facing trainees in practical skill acquisition in some TVET Colleges of Oromia regional state. This design was selected since it enables the researcher to describe, explain the nature and the extent of the problem in terms of number as well as in words discursively.

\subsection{Data Source}

Both primary and secondary sources were used in the study. Primary data were gathered from College Deans, training process owners, trainers/ instructors, sample departments of each stream and senior trainees of the selected colleges who are supposed to be data source of this study. The researchers used the data collecting instrument such as questionnaire and interview to collect the primary data. Secondary data were gathered from different literatures such as books, journals, research reports and documents to develop chapter two of this research that is the review of related literature.

\subsection{Samples and Sampling Techniques}

According to Kothari (2006), a researcher should determine his/her sample size to fulfill the requirement of efficiency, representatives and reliability. Based on this, the required pertinent informants were used in the following manner. There is 18 regional Zonal State found in the Oromia region, thus because of similarity of the 
College in the nature of the study concerned, three regional Zonal State were selected. The sample areas namely West Shewa Zone East Arsi Zone, Bale Zone and Finfine Special Zone were selected through stratified random Sampling

The total number of target population under study was 1200 from some selected colleges of Oromia regional state. From this target population, (15\%) 180 of the trainees and trainers/ instructors respondents were selected for the questionnaires. The college's senior trainees were selected through simple random sampling methods. Moreover, instructors/ trainers of each sample college were also be proportionally selected and be allocated from each departments. The Deans, training process owners and heads departments of each college were selected for the interview. Therefore, 2 TVET colleges were selected from East Arsi Zone, 1 TVET college from South West Shew Zone, 1 TVET College from Bale Zonal Administration and 1 TVET college found in Finfine Special Zone through Simple random Sampling. Therefore, totally 5 TVET Colleges were selected from three regional Zones

\subsection{Instrumentation and Methods \\ 3.4.1. Data Gathering Tools}

The intended information for this study was acquired through self report questionnaires and interview. The instruments were developed by the researchers' through English for the instructors of each stream of the colleges and the prepared tools were translated in to Afan Oromo to College's trainees and ' $\mathrm{C}$ ', level trainers for the convenience of communication.

\subsubsection{Pilot Study}

The pre-testing of the questionnaire was conducted with 24 respondents of Bureyu TVET College, selected randomly from some TVET colleges of Oromia regional state. These respondents were not a part of the actual sample of the study. The internal consistency reliability coefficient of the questionnaire was computed by the clombach alpha method for pretesting purpose to understand the reliability of the questionnaires and the computed reliability were .93. Respondents were encouraged to make useful suggestions by submitting written comments on items with ambiguities.

\subsubsection{Procedure for Data Collection}

The first step towards the collection of necessary data was made face to face contact with 5 Colleges Deans. On the other hand, colleges training process owners, department heads of each streams, instructors/ trainers and senior trainees were contacted for the task introducing the purpose of this study and were facilitate necessary condition during data collection. Some of the, Colleges instructors/ trainers and senior trainees who seek for explanations on some statements were given the necessary attention. Each college's trainees, instructors/trainers were contacted with the assistance of department heads of each stream of the colleges. Furthermore, Colleges trainees and instructors were contacted by the help of department heads of each stream of the colleges. The completed questionnaire were filled and be returned on the same day. Sample colleges Deans, Training process owners and department heads of each stream of the colleges were given information as a key informant interview.

\subsubsection{Methods of Data Analysis}

To analyze and interpret the data obtained from respondents' descriptive statistics was used. Arithmetic mean, standard deviation, and simple percentage were used. Simple percentage was used to classify and analyzed the relative standard characteristics of respondents such as sex, age, experience, level of education and position of the sample population. In line with this, all responses to open and closed ended items were organized, summarized and presented in word discursively

\subsubsection{Ethical consideration}

There are confident ethical protocols that have been followed in this research. The first is soliciting clearing agreement from the respondents. This ensures that their participation to this study is not out of their own wish. The researcher also makes sure that the respondents were conscious of the objectives of the research and their input to its completion. One other ethical gauge exercised by researcher is treating the respondents with respect and courtesy (Leary2004). This was done so that the respondents were at effortlessness and more likely to give truthful responses to the questionnaire. There were also ethical procedures that have been followed in the data analysis. To ensure the honesty of data, the researcher checked the correctness of encoding of the survey responses. This was carried out to ensure that the statistics generated from the study are truthful and verifiable (Leary 2004).

\section{Results and Discussions}

Results regarding the first research question: What are the challenges facing the trainees of some TVET Colleges of Oromia regional state? Means and standard deviations were used in answering these questions as Table1 displayed these results. 
A. Major Challenges facing trainees of same TVET Colleges of Oromia regional state

\begin{tabular}{|c|c|c|c|c|c|c|}
\hline \multirow[t]{2}{*}{ Items } & \multicolumn{3}{|c|}{ Responses of trainees } & \multicolumn{3}{|c|}{$\begin{array}{l}\text { Responses } \\
\text { trainers/instructors }\end{array}$} \\
\hline & $\mathrm{No} / \%$ & Mean & SD & $\mathrm{No} / \%$ & Mean & SD \\
\hline $\begin{array}{l}\text { There are sufficient practical skills training } \\
\text { for trainees in the college } \\
\text { A. Agree } \\
\text { B. Neutral } \\
\text { C. Disagree }\end{array}$ & $\begin{array}{l}88(71.6 \% \\
17(13.8 \%) \\
17(14.6 \%)\end{array}$ & 2.1 & 1 & $\begin{array}{l}38(80.8 \%) \\
6(12.8 \%) \\
2(4.3 \%)\end{array}$ & 1.9 & 0.9 \\
\hline $\begin{array}{l}\text { Trainees have adequate time to practice } \\
\text { Requisite practical skills at the college } \\
\text { during training } \\
\text { A. Agree } \\
\text { B. Neutral } \\
\text { C. Disagree }\end{array}$ & $\begin{array}{l}80(65 \%) \\
20(16.3 \%) \\
23(18.7 \%)\end{array}$ & 2.1 & 1.1 & $\begin{array}{l}19(40.4 \%) \\
7(14.9 \%) \\
21(44.7 \%)\end{array}$ & 3.1 & 1.5 \\
\hline $\begin{array}{l}\text { The practical component in technical } \\
\text { curriculum is effectively used in the college. } \\
\text { A. Agree } \\
\text { B. Neutral } \\
\text { C. Disagree }\end{array}$ & $\begin{array}{l}64(52 \%) \\
36(29.3 \%) \\
23(18.7 \%)\end{array}$ & 2.4 & 1.1 & $\begin{array}{l}30(63.8 \%) \\
7(14.9 \%) \\
9(3.8 \%)\end{array}$ & 2.8 & 3 \\
\hline $\begin{array}{l}\text { Project based training will help trainees in } \\
\text { acquiring practical skill Acquisition. } \\
\text { A. Agree } \\
\text { B. Neutral } \\
\text { C. Disagree }\end{array}$ & $\begin{array}{l}90(73.1 \%) \\
14(11.4 \%) \\
19(15.6 \%)\end{array}$ & 1.9 & 1.1 & $\begin{array}{l}38(80.9 \%) \\
5(10.6 \%) \\
3(8.5 \%)\end{array}$ & 1.8 & 1 \\
\hline
\end{tabular}

Source: researcher own survey construction in 2020

In Table 1 above item No 1 question concerning there are sufficient practical skill training for trainees in the college, majority of the trainees respondent were agreed to the issues, were as trainers were not agreed that trainees have no adequate time to practice request skills during practical skills training. (Mean Value 2.2 and 1.9) respectively on the bases of the individual observation. With regard to trainees have adequate time to practice requisite practical skills at the college during training, majority of the trainees respondents were agreed, while trainers are disagreed on the issue that trainees has no adequate time to practice request practical skills.(Mean Value 2.1 and 3.1) respectively. It is obvious that such dissimilar practices may occur due to distinction on the real observation among trainers and trainees. On the other hand, item No 3 of the same Table concerning the practical component in technical curriculum is effectively used in the college both trainees and trainers were agreed to the issue. Similarly, trainees and trainers were asked if the project based training will help trainees in acquiring practical skill acquisition. Accordingly, majority $90(73.1 \%)$ and $38(80.9 \%)$ of both trainees and trainers were agreed that project based training is very help full in acquiring practical skill acquisition.

B. Results related to the second research question:

To what extent does the trainers' qualifications and quality of training affects the training of Practical skills? .Trainees and trainers were used in answering these questions and the results are displayed in Table 2 below. 
Table 2 Description of trainees' respondents on the knowledge of trainers in practical skills

\begin{tabular}{|c|c|c|c|c|c|c|}
\hline \multirow[t]{2}{*}{ Items } & \multicolumn{3}{|c|}{ Responses of trainees } & \multicolumn{3}{|c|}{ Responses of trainers/instructors } \\
\hline & No/\% & Mean & SD & $\mathrm{NO} / \%$ & Mean & SD \\
\hline $\begin{array}{l}\text { There is Excessive absentees of trainers } \\
\text { during practical skill } \\
\text { A. Agree } \\
\text { B. Neutral } \\
\text { C. Disagree }\end{array}$ & $\begin{array}{l}56(45.6 \%) \\
29(23 . .6) \\
38(30.9 \%)\end{array}$ & 2.4 & 1.1 & $\begin{array}{l}15(31.9 \%) \\
10(21.3 \%) \\
22(46.8 \%)\end{array}$ & 3.2 & 1.2 \\
\hline $\begin{array}{l}\text { There is lack of knowledge by trainers } \\
\text { to use the existing tools and equipment } \\
\text { during practical training } \\
\text { A. Agree } \\
\text { B. Neutral } \\
\text { C. Disagree }\end{array}$ & $\begin{array}{l}52(42.3 \%) \\
21(17 \%) \\
50(40.7 \%)\end{array}$ & 2.65 & 1.2 & $\begin{array}{l}26(55.3 \%) \\
7(14.9 \%) \\
14(29.8 \%)\end{array}$ & 2.6 & 1.3 \\
\hline $\begin{array}{l}\text { Trainers follow Ethiopian occupational } \\
\text { standards to prepare Training Teaching } \\
\text { Learning(TTLM) Materials } \\
\text { A. Agree } \\
\text { B. Neutral } \\
\text { C. Disagree }\end{array}$ & $\begin{array}{l}91(74 \%) \\
11(8.9 \%) \\
21(17 \%)\end{array}$ & 2 & 1.1 & $\begin{array}{l}40(85.1 \%) \\
5(10.6 \%) \\
2(4.2 \%)\end{array}$ & 2.1 & 2.1 \\
\hline
\end{tabular}

Source: researcher own survey construction in 2020

In Table 2 above, item No 1 question entitled the excessive absentees of trainers during practical skill training greater number $56(39.4 \%)$ trainees were agreed to the issues. Were as $22(46.8 \%)$ of the trainers were disagreed on the bases of individual observation with (Mean value 2.4 and 3.2.) respectively. There is great distinction between mean of trainees and trainers that may occur are due to real practices of trainees' respondents. On the other hand, trainees and trainers respondents were asked if there is lack of knowledge by trainers to use the existing tools and equipment during practical skill training; accordingly, majority 52(42.3\%) and26 (55.3\%) of both trainees and trainers respondents respectively responded that there is a gap of trainers to use the existing tools and equipment during practical skill acquisition.

\section{Results related to 2 questions}

3. What are nature of connection that has been between the TVET Colleges of Oromia regional state and Industries? Both trainees and trainers were used in answering these questions and the results are presented in Table 3 below.

Table 3 Trainees and trainers view on attention given by the college towards industrial attachments.

\begin{tabular}{|c|c|c|c|c|c|c|}
\hline \multirow[b]{2}{*}{ Items } & \multicolumn{3}{|c|}{ Responses of trainees } & \multicolumn{3}{|c|}{ Response of trainers/instructors } \\
\hline & No/\% & Mean & SD & No/\% & Mean & SD \\
\hline $\begin{array}{l}\text { Little attention given by the college to } \\
\text { industrial attachments } \\
\text { A. Agree } \\
\text { B. Neutral } \\
\text { C. Disagree }\end{array}$ & $\begin{array}{l}66(53.7 \%) \\
21(17 \%) \\
36(29.3 \%)\end{array}$ & 2.6 & 1.1 & $\begin{array}{l}24(51.1 \%) \\
9(19.1 \%) \\
14(29.8 \%)\end{array}$ & 2.7 & 1.2 \\
\hline $\begin{array}{l}\text { Cooperative training is conducted in line } \\
\text { with competency out line } \\
\text { A. Agree } \\
\text { B. Neutral } \\
\text { C. Disagree }\end{array}$ & $\begin{array}{l}68(55.2 \%) \\
28(22.8 \%) \\
27(22 \%)\end{array}$ & 2.4 & 1.1 & $\begin{array}{l}28(59.5 \%) \\
1(12.7 \%) \\
13(27.6\end{array}$ & 2.3 & 1.2 \\
\hline $\begin{array}{l}\text { The time given by the college for the } \\
\text { cooperative training is sufficient } \\
\text { A. Agree } \\
\text { B. Neutral } \\
\text { C. Disagree }\end{array}$ & $\begin{array}{l}73(59.4 \%) \\
16(13 \%) \\
34(27.6 \%)\end{array}$ & 2.5 & 1.2 & $\begin{array}{l}31(65.9 \%) \\
6(12.7 \%) \\
10(27.3)\end{array}$ & 2.4 & 1.1 \\
\hline $\begin{array}{l}\text { Practical components in technical } \\
\text { curriculum are designed in collaboration } \\
\text { with the college and industries } \\
\text { A. Agree } \\
\text { B. Neutral } \\
\text { C. Disagree }\end{array}$ & $\begin{array}{l}40(32.5 \%) \\
41(33.3 \%) \\
42(34.2\end{array}$ & 2.9 & 1.1 & $\begin{array}{l}13(27.6 \%) \\
19(40.4 \%) \\
16(12.7 \%)\end{array}$ & 3 & 1 \\
\hline
\end{tabular}

Source: researcher own survey construction in 2020 
In Table 3 above item No 1 question entitled little attention is given to industrial attachments: The greater number $66(53.7 \%)$ and $24(51.4 \%)$ of the trainees and trainers were agreed that attention given to industrial attachments was found to be low. To correspond this, Akplu and Adamtey (2009) call for a merger between classroom and industry cooperative training in TVET for efficiency. They also identified placing TVET trainees in industries as one of the challenges of TVET Colleges. Moreover, study by (Bercovitz and al., 2001).examined by geographical proximity in the development of partnerships between colleges and industry are crucial. Furthermore, trainees and trainers were asked if cooperative training is conducted in line with competency out line; therefore, majority $68(55.2 \%)$ and $28(59.8 \%$ ) of them were respectively agreed with (Mean value $2.4 \& 2.3$ ) respectively. Item 3 the same Table concerning the time given by the college for the cooperative training is sufficient, majority $73(59.4 \%)$ and $31(65.9 \%)$ of both trainees and trainers respondents were agreed to the issues (Mean value 2.5 and 2.4) respectively. Moreover, trainees and trainers were asked if practical components in technical curriculum are designed in collaboration with the college trainers and industries expertise: Therefore, $42(34.2 \%)$ of trainees respondents partly agreed to the issue.

\section{Results related to question Number 4}

4.To what extents of practicum programs in achieving the objectives stated in its competency outline? Both trainees and trainers were used in answering these questions and the results are presented in Table 4 below.

Table 4: Responses on the trainers' supervision, provision of fund and practical skills achievement.

\begin{tabular}{|c|c|c|c|c|c|c|}
\hline \multirow[b]{3}{*}{ Items } & \multicolumn{6}{|c|}{ Respondent view } \\
\hline & \multicolumn{4}{|c|}{ Trainees $=123$} & \multicolumn{2}{|c|}{ Trainers $=47$} \\
\hline & NO & Mean & SD & No & Mean & SD \\
\hline $\begin{array}{l}\text { How far the practical training achieved } \\
\text { the objective Stated in its competency } \\
\text { outline? } \\
\text { A. Highly } \\
\text { B. Moderately } \\
\text { C. Lesser } \\
\text { D. Not at all }\end{array}$ & $\begin{array}{l}34(27.6 \%) \\
64(52 \%) \\
12(9.8 \%) \\
12(10.6 \%)\end{array}$ & 2 & 1 & $\begin{array}{l}8(17 \% \\
35(74.5 \%) \\
4(8.5 \%) \\
-\end{array}$ & 1.9 & 0.5 \\
\hline E. & 123 & & & 47 & & \\
\hline $\begin{array}{l}\text { Allocation of fund by the Oromia } \\
\text { TVET office for training } \\
\text { A. Very low } \\
\text { B. Low } \\
\text { C. Medium } \\
\text { D. I don't know }\end{array}$ & $\begin{array}{l}24(19.5 \%) \\
72(58.5 \%) \\
18(14.6 \%) \\
9(7.4 \%)\end{array}$ & 2.1 & 0.9 & $\begin{array}{l}11(23.4 \%) \\
21(44.7 \%) \\
13(27.7 \%) \\
2(4.3 \%)\end{array}$ & 2.6 & 0.7 \\
\hline
\end{tabular}

Source: researcher own survey construction in 2020

In Table 4 above both trainees and trainers were asked how far the practical training achieved the objective Stated in its competency outline: Accordingly, majority of them were responded to moderately (Mean value 2 and 1.9) respectively. In regard to item 2 both trainees and trainers were asked their evaluation on the allocation of fund and resource of the Oromia TVET commission for the training materials purchase in comparison with the College annual budget? Thus, majority of both trainees and trainers were respectively confirmed to low (Mean value $=\mathbf{2 . 1}$ and 2.6) respectively that there is by far discrepancy between trainees and trainers respondents. This variation may occur due to lack of awareness by trainees on the provision training budget by the Oromia TVET Commission.

\section{Conclusions}

From view point of findings obtained, the following main conclusions are generated.

It can be concluding from the study that the provision of training in the colleges and training provided in the company are not somewhat related. And the attention given to industrial attachments were found to be low. In line with this, trainees were attached to in company training at the end of the year and attachment of trainees to industries after completing each competency was not yet realized. Furthermore, there is poor preparation of TTLM by the trainers of the colleges, and the TTLM in the same module is different form department to department and from one college to another colleges. On the other hand the national assessment given to trainees has confined on the few competencies. More importantly, Occupational standard are prepared only by industries experts and collaborative preparation of occupational standard is not yet realized. Luck of TVET text book in all sample TVET colleges of Oromia Regional state Carelessness of trainers in applying their professional knowledge at practical skills and absence of spending their time during practical training were reported as one of the challenges that trainees are facing in acquisition of practical skills. 


\section{Recommendations}

Based on result obtained and the conclusions drown the following recommendations are forwarded;

1. This study found that the gap of knowledge of performance of trainers' in displaying the existing materials is recommended through in staff and in company training. Furthermore, the Colleges are advised to facilitate intra, interdepartmental and inter colleges experience sharing to build trainers capacity.

2. For the recognition of quality of practical skill training,

2.1. The College should strongly promote industrial attachment programmes for both trainers and trainees through their memorandum of agreements.

2.2. Concerned authority is advised to adopt project based training instead of competency based training which is currently in practice.

3. It was found that there is poor quality of TTLM preparation and the content of TTLM is varying from department to department and from college to college. Therefore, concerned authorities are advice to:

3.1. Train trainers on TTLM preparation procedures.

3.2. Crosse cheek the prepared TTLM with occupational standard and the TTLM are advised to be prepared centrally for the informality provision of training throughout the country

4. Occupational standard are advised to be prepared collaboratively by both industries and trainers of selected Colleges for the better quality of training.

5. It was found in the study that there are trainers who were carelessness in demonstrating their professional knowledge during practical skill, thus, serious emphasis should be given by concerned colleges officials/ leadership in preparing the program that participate all trainers.

\section{References}

African Union (2007). Strategy to revitalize technical and vocational Education and Training (TVET) in Africa Addis Ababa: Final Draft. Bureau of the Conference of Ministers of Education of the African Union (COMEDAF II + ).

Atchoaren, D. and A. Delluc (2002). Revisiting Technical and Vocational Education and Training in subSaharan Africa. Paris: STEDI

Amkombe (2000) Technical vocational education and training as a tool for sustainable development http:/www.wikieducator.org.images/b/b3/pid 431.PDF

Anamua-Mensah J. Towee P (2005). Bringing Industry into the Science Classroom: Problems, Concerns and Prospects Associated with Aparadigm Shift. Proceedings of the $7^{\text {th }}$ IOSTE Symposium in Netherlands.

Benelux Bologna Secretariat. (2009). BOLOGNA beyond 2010: Report on the development of the European Higher Education Area: Background paper for the Bologna Follow- Up Group. Paris, France: Author. Retrieved fromhttp://www.ehea.info/Uploads/LEUVEN/Beyond 2010_report_FINAL.pdf

Bercovitz, J., Feldman, M., Feller, I. \& Burton, R. (2001). Organizational structure as a determinant of academic patent and licensing behavior: An exploratory study of Duke, Johns Hopkins, and Pennsylvania State universities. The Journal of Technology Transfer, 26, 21-35

Bhuwanee, T. (2006). Reforming technical and vocational education in Sub-Saharan Africa: the Case studies of Ghana -Mauritius Tanzania and Zimbabwe. Dakar, Senegal:BREDA.

Hamaidi, I. Al-shara, Y. Arouri, and F. Abu Awwad, Student-Teacher"s perspectives of practicum practices and challenges. European Scientific Journal, 10 (13), 191-214, 2014

Ibe-Bassey, G. S. (2011). Human capacity building for information and communication technology (ICT) integration in teacher education in Nigeria. A Lead Paper presented at the 3rd international conference of Nigeria Association Educational Media and Technology (NAEMT).

ILO (2001). Modernization in Vocational Education and Training in the Latin American and the Caribbean Region. Montevideo.

Klein-Collins, R. (2014). Sharpening our focus on learning: The rise of competency- based approaches to degree completion (Occasional Paper \#20). Champaign, IL: National Institute for Learning Outcomes Assessment. Retrieved from http://learningoutcomeassessment.org/documents/Occasional\%20Paper\%2020.pdf.

Kofoworola, Hodkinson (2003). Learning to Change: Skills Development among the Economically Vulnerable and Socially Excluded in Developing Countries. Employment and Training Papers, 43, ILO, Geneva.

Kothari,C.R.2006. Research Methodology: Methods and Techniques. New - Delhi: New Age international Publishers.

Miller MD (1985). Principles and Philosophy of Vocational Education. Columbus: National Centre for Research into Vocational Education.

MoE(2008) ,.National Technical \& Vocational Education and Training Strategy

Nwosu, F. C. (2012). Using educational computer game to foster quality and functional engineering education among Nigerian youths. Multidisciplinary Journal of Research Development 17(4), 112

Obama, B. (2011, June 8). Office of the Press Secretary. Retrieved September 23, 2011, from Whitehouse.gov: 
http://m.whitehouse.gov/the-press-office/2011/06/08/ president-obamaand-skills-americas-future-partnersannounce-initiatives.

Odu OK (2011). Philosophical and sociological overview of vocational and technical education in Nigeria. American - Eurasian Journal of Scientific Research 6 (1).

Okebukola P (2012). Education, human security and entrepreneurship 7thConvocation Lecture of Delta State University, Abraka, University Printing Press.

Saaideh, M. A., \& Tareef, A. B. (2011). Vocational Teacher Education Research: Issues to Address and Obstacles to Face. Education, 131(4), 715+. Retrieved September 10, 2011, from Questia database: 545 tho09j.

Shanahan, M.; Hand, C. 2008. Skills development strategies for moving up the high road to development: The case of Ireland(Geneva, ILO, forthcoming).

Smith, \& L. Lev-Ari, The place of the practicum in pre-service teacher education: The voice of the students. Asia-Pacific Journal of Teacher Education, 33, 3, 289-302, 2005.

UNESCO-IICBA at the International National Qualification Framework (NQF) September 2011 in Hatfield, South AfricaUNESCO- IICBA and Microsoft-Ethiopia Symposium on 9

UNESCO (2003).Strengthening the Industry Linkages with TVET programs in Arab Countries through sector partnership. Beirut 